\title{
Digital PCR detection of plasmid DNA administered to the skeletal muscle of a microminipig: a model case study for gene doping detection
}

\author{
Teruaki Tozaki ${ }^{1,2^{*}} \mathbb{0}$, Shiori Gamo ${ }^{2}$, Masaki Takasu ${ }^{2}$, Mio Kikuchi ${ }^{1}$, Hironaga Kakoi ${ }^{1}$, Kei-ichi Hirota', \\ Kanichi Kusano ${ }^{3}$ and Shun-ichi Nagata ${ }^{1}$
}

\begin{abstract}
Objective: Doping control is an important and indispensable aspect of fair horse racing; genetic doping has been recently included to this. In this study, we aimed to develop a detection method of gene doping. A plasmid cloned with human erythropoietin gene ( $\mathrm{p} . \mathrm{hEPO}, 250 \mathrm{\mu g} / \mathrm{head}$ ) was intramuscularly injected into a microminipig. Subsequently, p.hEPO was extracted from $1 \mathrm{~mL}$ of plasma and detected by droplet digital polymerase chain reaction.

Results: The results confirmed that the maximum amount of plasmid was detected at 15 min after administration and the majority of the plasmid was degraded in the bloodstream within 1-2 days after administration. In contrast, low amounts of p.hEPO were detected at 2-3 weeks after administration. These results suggest that the proposed method to detect gene doping can help obtain information for experiments using horses.
\end{abstract}

Keywords: Gene doping, Horseracing, Plasmid, Thoroughbred

\section{Introduction}

During the early 1700s, horseracing was introduced in Britain with the development of thoroughbred horses by mating among Arabian stallions and British native mares [1]. As the horse racing industry has three main aspects, viz., breeding, racing, and wagering, fair horseracing management is extremely important. This can be accomplished through doping control.

The International Federation of Horseracing Authorities (IFHA) recently defined genetic therapy for racehorses to control gene doping [2]. Genetic therapy is defined as "the administration of oligomers or polymers of nucleic acid and nucleic acid analogues". In this context, polymers of nucleic acids and their analogues are considered as transgenes [3, 4], which have been linked to athletic performance in horses [5]. Therefore, the development of detection methods for these polymers is important to control gene doping. Several approaches, such as protein or transgene detection methods, have been considered for the detection of gene doping [6, 7].

Studies on the clearance of plasmids often use small experimental animals, such as mice $[8,9]$; however, there are only a few studies on medium- and/or large-sized animals. As the body size is significantly different between mouse and horse, it is not preferable to directly use the information obtained from mouse for horse, i.e., the amount of plasmid vector administered should be based on body weight conversion between them. In this study, the microminipig, which is a medium-sized animal, was used to investigate the clearance of plasmid DNA from blood, in order to apply the information obtained to horses. In this study, we aimed to develop a detection method of gene doping.

\footnotetext{
*Correspondence: ttozaki@lrc.or.jp

${ }^{1}$ Genetic Analysis Department, Laboratory of Racing Chemistry, 1731-2

Tsurutamachi, Utsunomiya, Tochigi 320-0851, Japan

Full list of author information is available at the end of the article
} 


\section{Main text}

\section{Ethical considerations}

This study was approved by the Committee for Animal Research and Welfare of Gifu University (No. 17122) and was conducted at the facility in Gifu University. Minimum number of animals was used in this model case study because of animal ethics and welfare. Furthermore, plasmid administration and blood sampling were performed after anesthetizing the animals to ensure that they are not stressed.

\section{Materials and methods}

The human erythropoietin (EPO) gene cloned into plasmid vector (p.hEPO) was procured (OriGene, Rockville, MD, USA), and then a large amount of p.hEPO was purified by transforming into Escherichia coli competent cell, JM109 (Takara Bio Inc., Shiga, Japan). The concentration $(n g / \mu \mathrm{L})$ of purified p.hEPO was measured using the Qubit dsDNA HS Assay Kit (Thermo Fisher Scientific, Waltham, MA, USA) and the copy number was measured by the droplet digital polymerase chain reaction (ddPCR; Bio-Rad, Hercules, CA, USA).

To detect p.hEPO by the ddPCR, the following TaqMan-MGB probe and primers were synthesized; probe (P3/4): CGACCTCCATCCTCTTC, forwardprimer (F3): TCCCAGACACCAAAGTTAATTTC, reverse-primer (R4): CCTGCCAGACTTCTACGG (Thermo Fisher Scientific). These were designed according to Baoutina et al. [7] to detect human EPO gene in the gene doping detection experiment.

For ddPCR, a method recommended by the manufacturer was used: $8.8 \mu \mathrm{L}$ of sample solution, $11 \mu \mathrm{L}$ of ddPCR Supermix for Prove (no dUTP), $0.2 \mu \mathrm{L}$ of $100 \mu \mathrm{M}$ F3-primer, $0.2 \mu \mathrm{L}$ of $100 \mu \mathrm{M}$ R4-primer, $0.6 \mu \mathrm{L}$ of $10 \mu \mathrm{M}$ P3/4-probe in the total volume of $22 \mu \mathrm{L}$. After creating a droplet with an Automated Droplet Generator (Bio-Rad), the PCR was carried out under the following conditions: enzyme activation reaction at $95{ }^{\circ} \mathrm{C}$ for $10 \mathrm{~min}, 40$ cycles of denaturation reaction at $94{ }^{\circ} \mathrm{C}$ for $30 \mathrm{~s}$ and annealing/ extension at $60{ }^{\circ} \mathrm{C}$ for $1 \mathrm{~min}$. After enzyme deactivation for $10 \mathrm{~min}$ at $98{ }^{\circ} \mathrm{C}$, the PCR products were stored at $12{ }^{\circ} \mathrm{C}$. Subsequently, the samples were measured using the QX200 Droplet Reader (Bio-Rad). Each ddPCR was performed using negative template controls (NTCs: MiliQ water or extracts from blank plasma) and positive template controls (PTCs: serially diluted p.hEPO).

One microminipig (male, 8-month old; 9.2 kg, FujiMicra, Shizuoka, Japan) was intramuscularly injected $250 \mu \mathrm{g}$ of p.hEPO, and then blood was sampled. Blood sampling was performed at $15 \mathrm{~min}, 3 \mathrm{~h}, 6 \mathrm{~h}, 12 \mathrm{~h}, 1$ day, 2 days, 3 days, 4 days, 5 days, 7 days, 2 weeks, and 3 weeks after administration. Four milliliters of blood was collected in an EDTA blood collection tube.
Immediately after sampling, the collected blood was centrifuged, and the plasma was separated and stored at $-20^{\circ} \mathrm{C}$. Then, p.hEPO was extracted from $1 \mathrm{~mL}$ of plasma with Chemagic Prepito (PerkinElmer, Waltham, MA, USA) using the Prepito Circulating NA $1 \mathrm{~K}$ Kit (PerkinElmer) by the magnetic bead method. The extract finally eluted is approximately $90 \mu \mathrm{L}$. In this study, the elution buffer provided in the kit was not used; instead we used Mili-Q. The recovery rate obtained by the ddPCR was $\sim 60 \%$ by the spike/recovery assays (data not shown).

\section{Results and discussion}

Figure 1 and Table 1 present the detection results of the ddPCR. At 15 min after administration, $2.5 \times 10^{6}$ copies were detected in $1 \mathrm{~mL}$ of plasma. Immediately after intramuscular injection, a large amount of p.hEPO circulated through the blood, and then was degraded in the blood within 2 days after the administration of p.hEPO.

Subsequently, a small amount of p.hEPO could be detected for 2-3 weeks after administration. We detected over $7 \times 10^{2}$ copies in $1 \mathrm{~mL}$ of plasma at 2 weeks and $\sim 1000$ copies in $1 \mathrm{~mL}$ of plasma at 3 weeks after administration. This might be due to the sustained release of p.hEPO remaining at the site of injection. It was indicated that almost all the plasmids were degraded in at least $1-2$ days.

Our results suggested that plasmid DNA administrated into body could be detected a few weeks after intramuscular injection. Therefore, the detection method used in this study (using $1 \mathrm{~mL}$ of EDTA plasma as a target substance and detection with ddPCR after DNA extraction) could help monitor gene therapy or detect gene doping.

In this study, $250 \mu \mathrm{g}$ of p.hEPO was administered to a microminipig (medium-sized animal) of body weight $9.2 \mathrm{~kg}$. As the average body weight of a 3-year-old thoroughbred racehorse (large sized-animal) is $473.9 \mathrm{~kg}$ [10], $250 \mu \mathrm{g}$ of p.hEPO should correspond to approximately $12.9 \mathrm{mg}$ in horses based on the body weight conversion. Therefore, if a horse is administered approximately $13 \mathrm{mg}$ of p.hEPO, the substance administered might be detected for approximately 2-3 weeks. During tendinitis treatment [11], the amount of plasmid detected might decrease compared with that observed in this study, as the amount of plasmid administered is only $\sim 5 \mathrm{mg} /$ horse.

\section{Conclusion}

It was demonstrated that the administered plasmid to animals could be detected in their blood samples by ddPCR, although this study was a model case study using a microminipig, which is a medium-sized animal. Therefore, it was considered that a similar approach is useful for gene doping detection in thoroughbred racehorses. Moreover, a suitable amount of plasmid that can be 


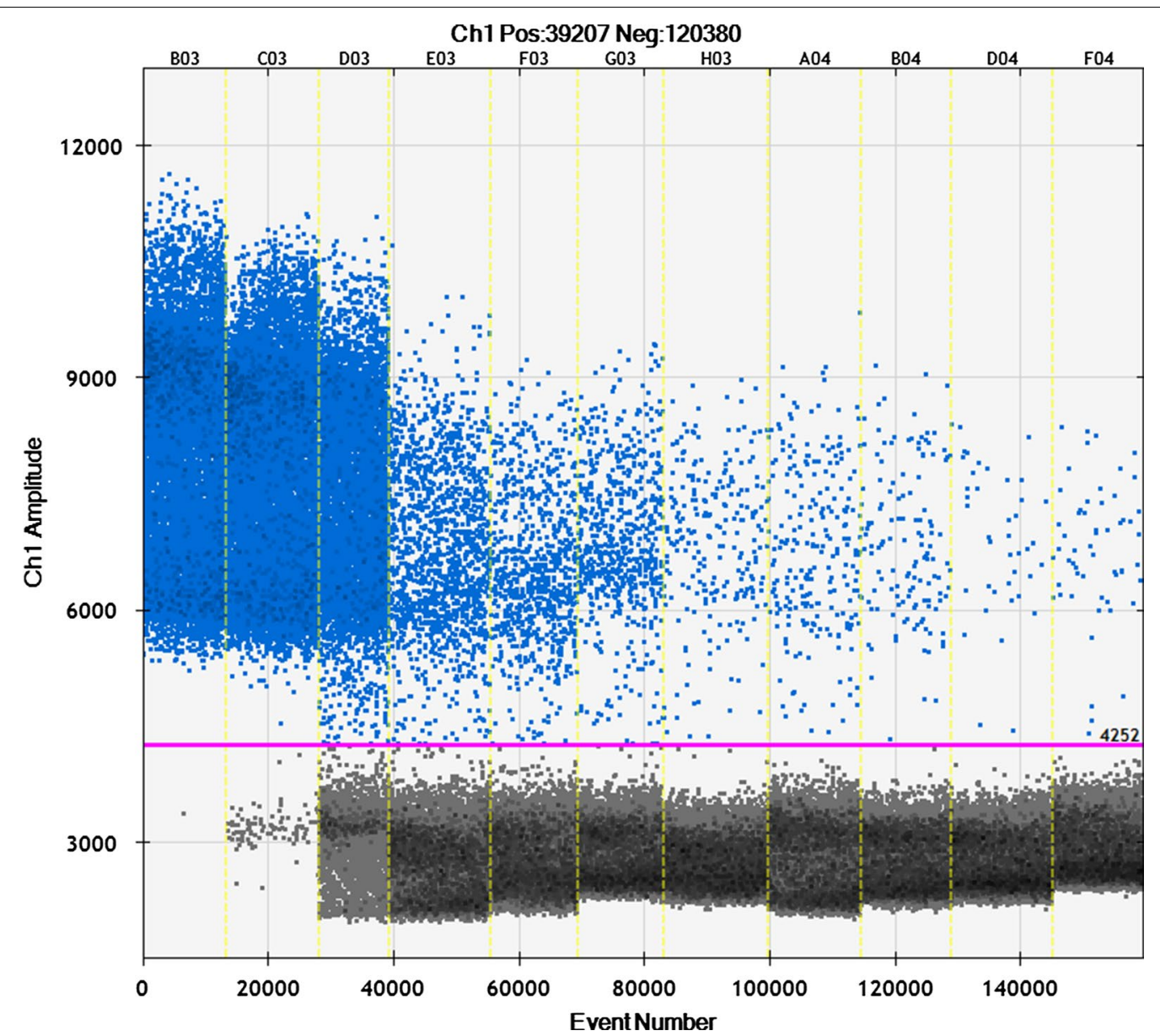

Fig. 1 Detection of p.hEPO in the plasma by ddPCR. Horizontal axis shows each sample (15 min, 6 h, 1 day, 2 days, 3 days, 4 days, 5 days, 6 days, 7 days, 2 weeks, and 3 weeks) after the administration of p.hEPO and vertical axis shows the amplitude of ddPCR products. Threshold line for non-amplified/amplified was manually defined at the amplitude of 4252 . At $15 \mathrm{~min}$ after administration, $2.52 \times 10^{6}$ copies in $1 \mathrm{~mL}$ plasma were detected, and then a large amount of p.hEPO was degraded in the blood within 1-2 days after administration

Table 1 Copy numbers detected in $1 \mathrm{~mL}$ of plasma by ddPCR

\begin{tabular}{ll}
\hline Collection time & $\begin{array}{l}\text { Copies } \\
\text { in } \mathbf{~ m L} \\
\text { of plasma }\end{array}$ \\
\hline 15 min & $2.52 \times 10^{6}$ \\
$6 \mathrm{~h}$ & $1.34 \times 10^{6}$ \\
1 day & $2.89 \times 10^{5}$ \\
2 days & $2.48 \times 10^{4}$ \\
3 days & $1.55 \times 10^{4}$ \\
4 days & $1.32 \times 10^{4}$ \\
6 days & $3.80 \times 10^{3}$ \\
7 days & $4.25 \times 10^{3}$ \\
2 weeks & $2.52 \times 10^{3}$ \\
3 weeks & 698 \\
\hline
\end{tabular}

administered to horses can be calculated by appropriate conversion based on the body weight of horse and microminipig.

\section{Limitations}

The limitation of this study is a case report that used one animal, microminipig, based on animal ethics. Therefore, studying with large sample size is recommended.

\footnotetext{
Abbreviations

ddPCR: droplet digital polymerase chain reaction; EPO: erythropoietin gene.

\section{Authors' contributions}

TT and MT conceived and designed the experiment; TT, SG, MT, MK, HK, KH, and SN performed the experiments; TT drafted the manuscript; KK provided critical comments and helped with results' discussion; all authors polished the paper, reviewed the manuscript. All authors read and approved the final manuscript.
} 


\section{Author details}

${ }^{1}$ Genetic Analysis Department, Laboratory of Racing Chemistry, 1731-2 Tsurutamachi, Utsunomiya, Tochigi 320-0851, Japan. ${ }^{2}$ Department of Veterinary Medicine, Faculty of Applied Biological Sciences, Gifu University, 1-1 Yanagido, Gifu, Gifu 501-1193, Japan. ${ }^{3}$ Racehorse Hospital Ritto Training Center, Japan Racing Association, 1028 Misono, Ritto, Shiga 520-3085, Japan.

\section{Acknowledgements}

We would like to thank Dr. Kurosawa M. for useful discussions and Ms. Tanaka N. for her assistance during this study. We would like to thank the Japan Racing Association for supporting this study through a grant-in-aid (2017-2019).

\section{Competing interests}

The authors declare that they have no competing interests.

\section{Availability of data and materials}

All the data supporting the findings is contained within the manuscript.

\section{Consent for publication}

Not applicable.

\section{Ethics approval and consent to participate}

This study was approved by the Committee for Animal Research and Welfare of Gifu University (No. 17122) and was conducted at the facility in Gifu University.

\section{Funding}

Japan Racing Association (JRA) supported this study through a grant-in-aid (2017-2019).

\section{Publisher's Note}

Springer Nature remains neutral with regard to jurisdictional claims in published maps and institutional affiliations.

Received: 2 August 2018 Accepted: 3 October 2018

Published online: 10 October 2018

\section{References}

1. Bower MA, Campana MG, Whitten M, Edwards CJ, Jones H, Barrett E, Cassidy R, Nisbet RE, Hill EW, Howe CJ, Binns M. The cosmopolitan maternal heritage of the Thoroughbred racehorse breed shows a significant contribution from British and Irish native mares. Biol Lett. 2011;7:316-20.

2. International Federation of Horseracing Authorities (IFHA). International agreement on breeding, racing and wagering (IABRW) 2018. https:// www.ifhaonline.org/resources/2018Agreement.pdf. Accessed 5 Oct 2018.

3. Collins M, Thrasher A. Gene therapy: progress and predictions. Proc Biol Sci. 2015;282:20143003.

4. Zhang Y, Satterlee A, Huang L. In vivo gene delivery by nonviral vectors: overcoming hurdles? Mol Ther. 2012;20:1298-304.

5. Wilkin T, Baoutina A, Hamilton N. Equine performance genes and the future of doping in horseracing. Drug Test Anal. 2017;9:1456-71.

6. Lasne F, Martin L, de Ceaurriz J, Larcher T, Moullier P, Chenuaud P. "Genetic Doping" with erythropoietin cDNA in primate muscle is detectable. Mol Ther. 2004;10:409-10.

7. Baoutina A, Coldham T, Bains GS, Emslie KR. Gene doping detection: evaluation of approach for direct detection of gene transfer using erythropoietin as a model system. Gene Ther. 2010;17:1022-32.

8. Kawabata K, Takakura Y, Hashida M. The fate of plasmid DNA after intravenous injection in mice: involvement of scavenger receptors in its hepatic uptake. Pharm Res. 1995;12:825-30.

9. Woo JG, Kim NY, Yang JM, Shin S. Biodistribution and blood clearance of plasmid DNA administered in arginine peptide complexes. Genet Vaccines Ther. 2011;9:13.

10. Tozaki T, Kikuchi M, Kakoi H, Hirota K, Nagata S. A genome-wide association study for body weight in Japanese Thoroughbred racehorses clarifies candidate regions on chromosomes 3, 9, 15, and 18. J Equine Sci. 2017;28:127-34.

11. Kovac M, Litvin YA, Aliev RO, Zakirova EY, Rutland CS, Kiyasov AP, Rizvanov AA. Gene therapy using plasmid DNA encoding vascular endothelial growth factor 164 and fibroblast growth factor 2 genes for the treatment of horse tendinitis and desmitis: case reports. Front Vet Sci. 2017:4:168.
Ready to submit your research? Choose BMC and benefit from:

- fast, convenient online submission

- thorough peer review by experienced researchers in your field

- rapid publication on acceptance

- support for research data, including large and complex data types

- gold Open Access which fosters wider collaboration and increased citations

- maximum visibility for your research: over $100 \mathrm{M}$ website views per year

At BMC, research is always in progress.

Learn more biomedcentral.com/submissions 